Zbornik Instituta za kriminološka

i sociološka istraživanja

2020 / Vol. XXXIX / 2-3 / 75-91

Pregledni naučni rad

Primljeno: 16. septembra 2020. godine

Prihvaćeno: 23. novembar 2020. godine

DOI: $10.47152 /$ ziksi2020235

UDK: $346.511(497.11)$

343.85:343.352(497.11)

\title{
NORMATIVNI OKVIR REPUBLIKE SRBIJE KOJIM JE REGULISANO PITANJE SUKOBA INTERESA - SA OSVRTOM NA PRAKSU AGENCIJE ZA SPREČAVANJE KORUPCIJE*
}

\author{
Aleksandar Stevanović*
}

\begin{abstract}
U radu je razmotren fenomen sukoba interesa u svetlu načina na koji je on određen i regulisan u zakonodavstvu Republike Srbije, odnosno kroz analizu prakse Agencije za sprečavanje korupcije. Na početku je dat prikaz normativnog okvira, koji uređuje materiju sukoba interesa, dok su naročito razmotrene odredbe Ustava Republike Srbije koje regulišu sukob interesa, te Zakona o sprečavanju korupcije kao sistemskog zakona iz ove oblasti. Sledi, analiza relevantnih odredbi sa ciljem da se razmotre određene nejasnoće u čemu je korišćena i praksa Agencije za sprečavanje korupcije, imajući u vidu njenu „kreativnu ulogu"naročito u konkretizaciji mnogobrojnih opštih $i$ pravnih standarda koji su karakteristični za odnosnu materiju. U delu rada koji se odnosi na zaključna razmatranja učinjene su pojedine napomene proistekle iz prethodne analize relevantnog zakonodavstua $i$ prakse Agencije, za koje autor rada veruje da mogu biti od koristi za poboljšanje normativnih kapaciteta i uopšte efikasnosti u nastojanjima da se sukob interesa kao izuzetno negativan društveni fenomen koji podriva fundamentalne postavke svakog demokratskog društua.
\end{abstract}

\footnotetext{
* Tekst je nastao kao rezultat rada na projektu „Kriminal u Srbiji: fenomenologija, rizici i mogućnost socijalne intervencije“ (broj 47011) finansiran od strane Ministarstva prosvete, nauke i tehnološkog razvoja Republike Srbije.

* Istraživač pripravnik u Institutu za kriminološka i sociološka istraživanja, Beograd. E-mail: aleksandar.stevanovic@iksi.ac.rs.
} 


\section{Zbornik IKSI, 2-3/2020 - A. Stevanović \\ „Normativni okvir Republike Srbije kojim je regulisano pitanje sukoba interesa - sa osvrtom na praksu Agencije za sprečavanje korupcije”, (str. 75-91)}

KLJUČNE REČI: sukob interesa / korupcija / demokratske institucije / javna ovlašćenja/ Agencija za sprečavanje korupcije/ Zakon o sprečavanju korupcije

\section{UVOD}

Sukobi različitih interesa sastavni su deo života u organizovanoj zajednici, te osnovano možemo tvrditi i da su neizostavni pratilac gotovo svake aktivnosti koja ima svoj cilj. Pri razmatranju fenomena sukoba interesa najčešce se i polazi od međusobnog odnosa privatnog i javnog interesa, u kojem potonji biva ugrožen i zanemaren na uštrb prethodnog. U osnovi se dakle, radi o potencijalnoj zloupotrebi javnih funkcija, odnosno postojanju opravdane bojazni da će privatni interes nosioca javne vlasti uticati na njegov rad u javnoj službi. Društvo svojim normama, bez obzira na njihovu pravnu kvalifikaciju i snagu, određuje koje su to situacije i okolnosti koje narušavaju princip nepristranosti, a koji smatramo fundamentalnim uslovom za poverenja građana u institucije vlasti, bez čega ne može ni postojati „funkcionalni demokratski poredak“ (Stevanović, 2019: 308)

Dosadašnje iskustvo je pokazalo da je postojanje i snažan uticaj privatnih interesa predstavnika javne vlasti, često dijametralno suprotnih onim koje društveni konsenzus određuje kao opšti, istorijska konstanta političkog života od nastanka moderne države. Pravna istorija beleži propise poput Lex Sillia, Lex Calpurmia, Lex Acilia, Lex Tullia, koji su između ostalog, regulisali zloupotrebe od strane nosilaca javne vlasti (Vuković, 2003: 8), što ukazuje na činjenicu da su različite forme zloupotreba javne vlasti bile prisutne kroz celu pisanu istoriju društva i čovečanstva, a naročito na svest o posledicama postojanja sukoba javnih i privatnih interesa, koja je prisutna još od antičkih vremena. Ta svest oblikovana je različitim društvenim, političkim, kulturološkim i ekonomskim okolnostima, uz nemerljiv doprinos filozofske misli mnogobrojnih autora, naročito onih koji su stvarali u periodu formiranja prvih građanskih društava. Na taj način stvarana je svojevrsna pravna kultura koja ima svoj odraz u (ne)postojanju određenih propisa, kvalitetu postojećih propisa, te obimu njihove primene. U osnovi, pravo oblikuje i usmerava sve društvene tokove, a u moderno vreme ono tu svoju funkciju ostvaruje kroz pravne propise iz čega proizlazi da je pitanje sukoba interesa neraskidivo povezano sa odnosom vlasti prema pravnom propisu.

U opštem, medijskom, ali i akademskom diskursu, pojam sukoba interesa se često pored poistovećivanja sa korupcijom, pogrešno izjednačava i meša sa pojavama poput kumuliranja više javnih funkcija i dužnosti, istovremenog obavljanja političkih i državnih funkcija, neprijavljivanja imovine od strane javnih funkcionera, primanja poklona,pantoflaže, nepotizma, kronizma i tome slično. Navedene pojave su nedvosmisleno inherentne pojmu o kojem govorimo uz opasku da ne odražavaju njegovu suštinu u punom obimu te se ipak ne mogu dovesti u sinonimski odnos. 
Zbornik IKSI, 2-3/202O - A. Stevanović

„Normativni okvir Republike Srbije kojim je regulisano pitanje sukoba interesa - sa osvrtom

na praksu Agencije za sprečavanje korupcije”, (str. 75-91)

\section{OSVRT NA GLAVNE KRIMINOLOŠKO-PRAVNE KARAKTERISTIKE POJMA SUKOB INTERESA}

Jedan od značajnijih teoretičara države i društva u XVIII veku, čuveni francuski mislilac Šarl Monteskje (Charles Montesquieu), zapisao je u svom kapitalnom delu „O duhu zakona“ da je svaka vlast sklona zloupotrebi i kvarenju, te da ju je neophodno ograničiti drugom vlašću (Vuković, 2003: 10). Na tragu te ideje, a u cilju načelnog određivanja pojma „sukob interesa“ primećujemo da se upravo nepostojanje međusobnog i odgovarajućeg ograničenja javne vlasti može označiti kao stanje koje pogoduje razvoju situacija koje dovode u konflikt javni i privatni interes.

Fenomen sukoba interesa je $u$ tesnoj vezi sa korupcijom i to na način da čini njenu osnovu (Rao, Marquette, 2012: 12). Takvo stanje stvari uzrokovano je bitno istovrsnim etiološkim, fenomenološkim i posledičnim aspektima, te je u doktrini često zastupljen stav da su sukob interesa i korupcija praktično dva termina koji označavaju identičnu pojavu. Ipak, sukob interesa kao poseban, pre svega normativni pojam, ima širi sadržinski domašaj, te ga je neophodno razmotriti ne samo kao glavno polazište svakog koruptivnog odnosa, već kao samostalni pojam koji u mnogome zavisi od stanja demokratije, kulturološke podloge, te pozitivnih propisa koje oblikuju prethodna dva faktora.

Sukob interesa, grosso modo, podrazumeva konflikt između obavljanja javne dužnosti i privatnog interesa lica koje tu dužnost obavlja (Vukadinović, Glintić, 2013: 89), odnosno situaciju u kojoj lični interes nadvladava i utiče na objektivno izvršavanje profesionalnih obaveza (Nenadić, 2003: 5). Sukob interesa nastaje onda kada postoji društveno neprihvatljiva percepcija sukoba između interesa koje javni funkcioner ima kao privatno lice i onih interesa kojima bi on morao da teži zarad obavljanja svojih dužnosti u skladu sa zakonom (Fatić, 2005: 32). Otuda, sama okolnost ili situacija postojanja potencijalnog konflikta privatnog i javnog interesa u vršenju javne službe jeste štetna po društveni poredak $i$ to naročito u smislu odnosa građana prema institucijama vlasti, bez obzira na to da li je iz te situacije zaista proistekao konkretan delikt, odnosno da li je nosilac javne vlasti stekao određenu privilegiju ili korist, protivno javnom interesu i zakonu (Kemaghan, Langford, 1990: 139). Iz ovoga proističe da sukob interesa može biti shvaćen i kao akt (situacija) protiv poverenja u javnu vlast, a o kolikoj se društvenoj šteti radi govori i činjenica da se na pretpostavci međusobnog poverenja zasnivaju svi međuljudski odnosi (Luhman, 1979: 64), a naročito oni u kojima strane nisu jednake, kao što je to slučaj u odnosu građanin - država.

$\mathrm{Na}$ rasprostranjenost različitih sukoba javnog i privatnog interesa ukazuju i mnogobrojne analize empirijskih podataka prema kojima je zloupotreba javnih ovlašćenja pojava imanentna kako nerazvijenim državama u društvenoekonomskom pogledu, tako i onim državama koje se smatraju stabilnim liberalnodemokratskim porecima (Jovanović, 2007: 29). Uzevši u obzir takvu kosmopolitsku prirodu sukoba interesa, u smislu uticaja privatnih interesa na obavljanje javnih funkcija, nameće se i potreba adekvatne zakonodavne aktivnosti, koja pak ne može 


\author{
Zbornik IKSI, 2-3/2020 - A. Stevanović \\ „Normativni okvir Republike Srbije kojim je regulisano pitanje sukoba interesa - sa osvrtom \\ na praksu Agencije za sprečavanje korupcije”, (str. 75-91)
}

na pravi način odgovoriti zadatku ukoliko se prethodno, na teorijskom planu, jasno ne definiše etiološka i fenomenološka komponenta pojma. Tek nakon toga je moguće kreirati normativni okvir koji bi uvažio realne okolnosti i iz koga bi se jasno prepoznavale intencije javne politike kada je reč o ovoj oblasti društvenog života.

\title{
2. NORMATIVNI OKVIR U REPUBLICI SRBIJI - KONKRETIZACIJA RELEVANTNIH NORMI KROZ ANALIZU PRAKSE AGENCIJE ZA SPREČAVANJE KORUPCIJE
}

Zakon o sprečavanju sukoba interesa pri vršenju javnih funkcija, koji je stupio na snagu 2004. godine, bio je prvi zakonski akt koji je na sistemski način uredio oblast sukoba interesa u Republici Srbiji. Gotovo godinu dana po stupanju na snagu navedenog Zakona, formiran je Republički odbor za rešavanje o sukobu interesa, sa zadatkom da sprovodi njegove odredbe koje regulišu sukob interesa (Stevanović, 2019: 318).

Republika Srbija je 2006. godine dobila novi, tzv. „Mitrovdanski ustav“, te je njegovim izglasavanjem i stupanjem na snagu, zabrana sukoba interesa uzdignuta $u$ rang ustavnog načela. ${ }^{1}$ Republika Srbija spada u red država koje su pitanje sukoba interesa prepustile zakonskom uređivanju, nasuprot onim državama koje odnosnu materiju uređuju isključivo donošenjem etičkih kodeksa o ponašanju javnih funkcionera (Lubarda, 2007: 200). ${ }^{2}$

Zakon o sprečavanju sukoba interesa pri vršenju javnih funkcija zamenio je Zakon o agenciji za borbu protiv korupcije koji je u primeni od 2008. godine i koji je na sistemski3 način regulisao materiju sukoba interesa u Republici Srbiji. Njegovim usvajanjem učinjene su krupne promene u oblasti borbe protiv korupcije uopšte, pa tako i sprečavanja sukoba interesa, naročito zbog osnivanja Agencije za borbu protiv korupcije.

U maju 2019. godine izglasan je novi, seades materiae propis u oblasti sprečavanja sukoba interesa, Zakon o sprečavanju korupcije ${ }^{4}$ (dalje: ZSK) čija je primena otpočela 01. septembra 2020. godine, osim odredbi iz člana 20. stav 2. i čl. 21. do 25. koje su u primeni od stupanja na snagu navedenog Zakona.

\footnotetext{
${ }^{1}$ To proizlazi iz člana 6. Ustava RS („Sl. glasnik RS, br. 98/2006) koji određuje da: „Niko ne može vršiti državnu ili javnu funkciju koja je u sukobu sa njegovim drugim funkcijama, poslovima ili privatnim interesima.“ Stavom 2. istog člana je predviđeno da se „Postojanje sukoba interesa i odgovornost pri njegovom rešavanju određuju Ustavom i zakonom."

${ }^{2}$ U literaturi se najčešće navodi prime Velike Britanije gde je pitanje postojanja i rešavanja o sukobu interesa uređeno pravilnikom Parlamenta - Code of Conduct for the members of the Parliament (Lubarda, 2007: 200).

3 To znači da on, za razliku od drugih zakonskih propisa koji shodno svojoj oblasti, utvrđuju zabrane sukoba interesa u konkretnom slučaju, predviđa i mehanizme za otkrivanje, prijavljivanje i rešavanje o sukobu interesa.

${ }_{4}$ Zakon o sprečavanju korupcije ("Sl. glasnik RS", br. 35/2019).
} 


\section{Zbornik IKSI, 2-3/2020 - A. Stevanović \\ „Normativni okvir Republike Srbije kojim je regulisano pitanje sukoba interesa - sa osvrtom na praksu Agencije za sprečavanje korupcije”, (str. 75-91)}

Pored navedenih propisa, materija sukoba interesa regulisana je i drugim zakonskim i podzakonskim propisima, poput Zakon o državnim službenicima, $5 \mathrm{~s}$ tim da u tim slučajevima zakonsko regulisanje ima parcijalni obim primene u pogledu adresata normi i situacija na koje se ono odnosi.

Agencija za sprečavanje korupcije u skladu sa odredbom člana 6. stav 1. tačka 11. pored ostalih Zakonom uspostavljenih nadležnosti, daje mišljenja o primeni ovog Zakona na sopstvenu inicijativu ili na zahtev fizičkih ili pravnih lica i zauzima stavove od značaja za njegovu primenu. Imajući u vidu „bezobalnu“ prirodu sukoba interesa koji nije moguće predvideti sa svaku pojedinačnu situaciju i precizno ga odrediti, kreativna uloga Agencije u formiranju i tumačenju prava, od nesumnjivog je značaja za valjanu primenu odredbi koje nastoje da urede odnosnu materiju. Agencija tu svoju „kreativnu ulogu“ ostvaruje dajući mišljenja, bez pravno obavezujućeg karaktera, koja interpretiraju ponekad nedovoljno određene norme i dopunjuju ih u situacijama u kojima se javlja tzv. „pravna praznina“.

\subsection{Ustav Republike Srbije}

Ustav Republike Srbije ${ }^{6}$ (dalje: URS) načelno određuje da: „Niko ne može vršiti državnu ili javnu funkciju koja je u sukobu sa njegovim drugim funkcijama, poslovima ili privatnim interesima.“, dok stavom 2. istog člana predviđa da se „Postojanje sukoba interesa i odgovornost pri njegovom rešavanju određuju Ustavom i zakonom.“.

U duhu prihvaćene, trodome, podele vlasti, u domaćem pravnom sistemu narodni poslanik ne može biti poslanik u skupštini autonomne pokrajine, niti funkcioner $\mathrm{u}$ organima izvršne vlasti i pravosuđa, niti može obavljati druge funkcije, poslove i dužnosti za koje je zakonom utvrđeno da predstavljaju sukob interesa. Na ovom mestu bi valjalo učiniti osvrt na dva važna pitanja.

Najpre, proizlazi da ne postoji ograničenje da narodni poslanik bude odbornik u skupštini jedinice lokalne samouprave, što smatramo neopravdanim rešenjem. To iz razloga što odluke Narodne skupštine, u čijim donošenjima (izglasavanjima) učestvuje i poslanik koji je ujedno i odbornik u skupštini jedinice lokalne samouprave, mogu itekako uticati na društveno-ekonomski život te jedinice lokalne samouprave, pri čemu poslanik koji se nađe u „dvostrukoj predstavničkoj“ ulozi može biti vođen isključivo privatnim interesima koji po pravilu škode opštem interesu.

Predviđen je i zabrana narodnom poslaniku da obavljanje funkcija, poslove i dužnosti za koje je zakonom utvrđeno da predstavljaju sukob interesa. Striktno posmatrano, to bi značilo da će se narodni poslanik naći u sukobu interesa samo

\footnotetext{
5 Zakon o državnim službenicima ("Sl. glasnik RS", br. 79/2005, 81/2005 - ispr., 83/2005 - ispr., 64/2007, 67/2007 - ispr., 116/2008, 104/2009, 99/2014, 94/2017 i 95/2018).

${ }^{6}$ Ustav Republike Srbije („Sl. glasnik RS, br. 98/2006).
} 


\section{Zbornik IKSI, 2-3/2020 - A. Stevanović \\ „Normativni okvir Republike Srbije kojim je regulisano pitanje sukoba interesa - sa osvrtom na praksu Agencije za sprečavanje korupcije", (str. 75-91)}

onda kada je zakonskim aktom predviđeno da određeni status i aktivnosti narodnog poslanika predstavljaju sukob interesa. Takav pristup bi zbog svog prekomernog formalizma isključio mnogobrojne situacije (statuse i aktivnosti) u kojima se može naći narodni poslanik, a koje usled tako uskog pristupa ne bi bile tretirane kao sukob interesa, budući da nije za očekivati da zakonodavac sve potencijalne situacije koje mogu voditi ka sukobu interesa predvidi i obuhvati normom. U tom smislu, značajna je teorijska podela na sukob interesa u užem i širem (diskrecionom) smislu (Stevanović, 2019: 311). U prvom slučaju je reč o situacijama koje je društvo prepoznalo kao opasne po javni interes do te mere da ih je zakonodavac morao predvideti i pravno kvalifikovati kao sukob interesa, bez potrebe da se bilo kakvo telo izjašnjava o njegovom eventualnom postojanju u datim okolnostima. Drugim rečima, takve situacije su neprihvatljive u procesu vršenja javne vlasti da čak nije potrebno ni da iz njih nastane određena štetna posledica, tj. one deluju i suviše motivišuće na zloupotrebu javnih ovlašćenja, da društvo nije spremno da ishod prepusti etičnosti konkretnog funkcionera. Iz tog razloga, nadležno telo ce samo konstatovati postojanje sukoba interesa na osnovu objektivnih okolnosti, koje su pozitivnom normom predviđene kao sukob interesa. Otuda možemo zaključiti da u takvim situacijama postoji neoboriva pretpostavka o postojanju sukoba interesa.7

U drugom slučaju, sukob interesa obuhvata i takve okolnosti u odnosu na koje se ne može sa sigurnošću, jednostavnim podvođenjem činjeničnog stanja pod pravnu normu, utvrditi postojanje sukoba interesa, niti se on može regulisati normom u svakom potencijalnom slučaju sukoba. ${ }^{8}$ Tu je dakle u pitanju oboriva pretpostavka o postojanju sukoba interesa koji se mora utvrđivati prema opštim normama koje se odnose na zabranu sukoba interesa. Takve su primera radi odredba člana 6 . URS ili odredba člana 40. ZSK.

Agencija za sprečavanje korupcije (dalje: Agencija) prihvata širu koncepciju sukoba interesa, što je apsolutno u skladu sa duhom propisa koji regulišu odnosnu materiju. Tako kada je reč o sukobu interesa odbornika skupštine opštine utvrđuje da se on nalazi u sukobu interesa kada istovremeno sa tom funkcijom obavlja dužnost predsednika ili člana saveta određene mesne zajednice. ${ }^{9}$ Agencija je navedeno utvrdila pozivajući se na opštu odredbu koja na uopšten način zabranjuje sukob interesa, a ne iz razloga što je zakonskom odredbom izričito predviđena zabrana

\footnotetext{
7 Eklatantan primer za navedeno jeste zabrana na strani sudija da istovremeno vrše funkcije $\mathrm{u}$ organima izvršne vlasti. Pored toga, postoji i zabrana pripadnicima oružanih snaga da budu članovi političkih stranaka, zabrana javnim funkcionerima da istovremeno budu u organima upravljanja privrednih društava itd.

${ }^{8}$ Važno je istaći da sukob interesa u širem (diskrecionom) smislu ima neograničen broj formi. Tu međutim iz praktičnih razloga valja praviti razliku u odnosu na predviđenost takvih situacija u zakonskim ili podzakonskim tekstovima. Prethodno smo istakli da postoje načini realizacije mogućnosti zloupotrebe javnog ovlašćenja (nepotizam, kronizam) koji uglavnom nisu zakonski normirani. U takvim slučajevima je posebno važno stanje svesti društva, tj. kulturološka osnova poimanja javne službe i vlasti uopšte, koja kreira društvenu toleranciju na pojave koje imaju kapacitet da ugroze nepristrasnost u donošenju javnih odluka.

9 Mišljenje Agencije za sprečavanje korupcije broj: 014-011-00-0189/17-11
} 


\section{Zbornik IKSI, 2-3/2020 - A. Stevanović \\ „Normativni okvir Republike Srbije kojim je regulisano pitanje sukoba interesa - sa osvrtom na praksu Agencije za sprečavanje korupcije", (str. 75-91)}

odborniku skupštine opštine da istovremen bude predsednik ili član saveta mesne zajednice. U konkretnom slučaju, Agencija je zaključila da: „Odbornik skupštine opštine ne može istovremeno da bude predsednik, odnosno član saveta mesne zajednice koje su osnovane na teritoriji iste opštine, jer je to u suprotnosti sa obavezom funkcionera propisanom odredbama čl. 27. st. 2. i 3. Zakona o Agenciji, na osnovu kojih je funkcioner dužan da stvara i održava poverenje građana u savesno i odgovorno vršenje javne funkcije i da izbegava stvaranje odnosa zavisnosti prema licu koje bi moglo da utiče na njegovu nepristrasnost u vršenju javne funkcije.“

Obrazlažući dalje navedeno Mišljenje, Agencija se pozvala na odredbe Zakona o lokalnoj samoupravi ${ }^{10}$ navodeći da je: „Odredbama čl. 73, 75. i 77. st. 1. navedenog Zakona propisano da skupština opštine, odlučuje o obrazovanju, području za koje se obrazuje, i ukidanju mesnih zajednica, da se sredstva za rad mesne zajednice obezbeđuju, pored ostalog, iz sredstava utvrđenih odlukom o budžetu opštine, da mesna zajednica donosi finansijski plan na koji saglasnost daje nadležni organ opštine i da se odlukom skupštine opštine može svim ili pojedinim mesnim zajednicama poveriti vršenje određenih poslova iz nadležnosti opštine, uz obezbeđivanje za to potrebnih sredstava." iz čega zaključuje da u konkretnom slučaju postoji odnos zavisnosti između funkcije odbornika skupštine opštine i predsednika ili člana saveta mesne zajednice, koji bi mogao da utiče na nepristrasnost funkcionera.

Agencija se u svom radu osvrnula i na situaciju postojece kumulacije funkcije narodnog poslanika - predsednika Odbora za obrazovanje, nauku, tehnološki razvoj i informatičko društvo, i predsednika privatnog Univerziteta. ${ }^{11}$ Tom prilikom, najpre je istakla činjenicu da u skladu sa pozitivnim propisima, o akreditaciji univerziteta odlučuje Komisija za akreditaciju i proveru kvaliteta (dalje: Komisija) koju kao posebno telo obrazuje Nacionalni savet, čije članove bira Narodna skupština. Komisija podnosi Nacionalnom savetu izveštaj o svom radu, dok Nacionalni savet podnosi izveštaj o svom radu Narodnoj skupštini najmanje jedanput godišnje. Imajući sve navedeno u vidu, Agencija, prema našem mišljenju, propušta da konkretnu situaciju oceni kao postojeći sukob interesa, pozivajući se na činjenicu da Odbora za obrazovanje, nauku, tehnološki razvoj i informatičko društvo, na čijem je čelu narodni poslanik, nema ovlašćenje da u prvom ili drugom stepenu odlučuje i donosi pojedinačne akte $u$ vezi sa akreditacijom ustanova i studijskih programa $u$ oblasti visokog obrazovanja. Agencija zauzimajući takav stav očigledno nije uzela za relevantnu okolnost to da je odnosni Odbor radno telo Narodne skupštine, kojoj tela nadležna za odlučivanje o radu ustanova u oblasti visokog obrazovanja (Komisija i Nacionalni savet) podnose izveštaje i čije članove bira upravo Narodna skupština, čiji je član i predsednik Odbora za obrazovanje, nauku, tehnološki razvoj i informatičko društvo, a koji je ujedno i predsednik privatnog Univerziteta. Međutim, Agencija u konkretnom Mišljenju navodi da data situacija predstavlja potencijalni sukob

\footnotetext{
${ }_{10}$ Zakon o lokalnoj ("Sl. glasnik RS", br. 129/2007, 83/2014 - dr. zakon, 101/2016 - dr. zakon i 47/2018)

${ }^{11}$ Mišljenje Agencije za sprečavanje korupcije broj: 014-011-00-0167/16-11
} 


\section{Zbornik IKSI, 2-3/2020 - A. Stevanović \\ „Normativni okvir Republike Srbije kojim je regulisano pitanje sukoba interesa - sa osvrtom na praksu Agencije za sprečavanje korupcije”, (str. 75-91)}

interesa iz razloga što Odbor na čijem je čelu ujedno i predsednik privatnog Univerziteta utvrđuje predlog naknade za rad članova Komisije, odnosno razmatra izveštaje koje Komisija podnosi Narodnoj skupštini preko Nacionalnog saveta.

Usled konstatovanog potencijalnog sukoba interesa, Agencija u Mišljenju navodi da će u budućem periodu, po službenoj dužnosti, pratiti konkretnu kumulaciju zbog postojanja utvrđenih okolnosti koje mogu uticati na narodnog poslanika predsednika Odbora, da svoju funkciju obavlja pristrasno, imajući u vidu njegov privatni interes koji se reflektuje u oblasti rada i ingerencija Odbora na čijem je čelu. Na kraju, Agencija je konstatovala da bi se u konkretnom slučaju radilo o postojećem sukobu interesa, ukoliko bi konkretno lice - predsednik Odbora i narodni poslanik, svoju poslaničku funkciju vršilo na stalnom radu, što proizlazi iz odredbe člana 33. stav 2. ranijeg Zakona o agenciji za borbu protiv korupcije. Iznenađujuće je da Agencije, u predmetnom slučaju nije utvrdila da li se narodni poslanik i predsednik Odbora za obrazovanje, nauku, tehnološki razvoj i informatičko društvo zaista nalazi u stalnom radu, što je relativno lako proverljiva činjenica koja bi bila od uticaja na davanje konkretnijeg mišljenja, te kasnije i efikasnijeg suzbijanja, adekvatnim pravnim sredstvima, uočenog nedozvoljenog sukoba interesa.

Kada je reč o predsedniku Republike, URS uvažavajući činjenicu da bi on trebalo da izražava državno jedinstvo, te da bude predsednik svih građana, predviđa da on ne može obavljati drugu javnu funkciju ili profesionalnu delatnost.“

Pitanje inkompatibilnosti funkcija šefa države i predsednika političke stranke, jedno je od zanimljivijih u modernoj istoriji našeg konstitucionalizma. Iako je prethodni Ustav iz 1990. godine regulisao nespojivost predsedničke funkcije sa drugim javnim funkcijama i profesionalnim delatnostima, na način koji je izazivao obimne rasprave i nesuglasice, ustavotvorac "Mitrovdanskog ustava“ propustio je da preciznijim normiranjem ove materije otkloni nejasnoce, te da odgovori na pitanje koje se nekoliko decenija unazad iznova aktuelizuje: Može li predsednik republike istovremeno biti i predsednik političke stranke, odnosno član njenog rukovodstva ili član bez dodatnih upravljačkih prava u njoj?

Smatramo da bi na postavljeno pitanje trebalo odgovoriti pre negativno, nego pozitivno, iako se mogu pronaći argumenti i za suprotan stav. Slično mišljenje je pretežno zastupljeno i u domaćoj literaturi (Čavoški, 1995: 141; Stojanović, 1991: 92). Razloge bismo mogli potražiti u analizi pojma „javna funkcija“ i „profesionalna delatnost“, te u teleološkom i sistemskom tumačenju važećeg URS.

Prvo, u političkom diskursu, pod javnom funkcijom se podrazumeva vršenje određene izborne javne aktivnosti u političkoj organizaciji, predstavničkom organu, radnoj organizaciji ili upravi, dok se u kontekstu pravničkog diskursa, tu podrazumeva delatnost, odnosno aktivnost vršenjem određenog poziva ili službe, zadatak ili grupa zadataka, uloga ili uticaj koji neko vrši u državnoj vlasti, društvenim odnosima ili javnom životu i pravosuđu.

Pojam ,javna funkcija“ definisan je u Zakonu o sprečavanju korupcije i pa je tako predviđeno da ona podrazumeva funkciju koju vrši javni funkcioner. Pojam ,javni funkcioner“ definisan je tako da on predstavlja svako izabrano, postavljeno ili 


\section{Zbornik IKSI, 2-3/2020 - A. Stevanović \\ „Normativni okvir Republike Srbije kojim je regulisano pitanje sukoba interesa - sa osvrtom na praksu Agencije za sprečavanje korupcije”, (str. 75-91)}

imenovano lice $\mathrm{u}$ organu javne vlasti, osim lica koja su predstavnici privatnog kapitala u organu upravljanja privrednog društva koje je organ javne vlasti, pa se na taj način, posredno određuje i pojam javne funkcije.

Navedenu odredbu je moguće tumačiti na način da predsednik političke stranke nije javna funkcija iz razloga što istu ne vrši lice označeno kao javni funkcioner. Međutim, usled nedovoljne preciznosti novog zakonskog rešenja, moguće je i suprotno tumačenje. To iz razloga što bi se moglo isticati da ukoliko je već javna funkcija ona koju vrši javni funkcioner, onda je i mesto predsednika političke stranke funkcija, zato što se na njemu nalazi javni funkcioner, odnosno zato što je vrši javni funkcioner, primera radi, predsednik države kao izabrano lice. U tom smislu, smatramo da je rešenje prethodnog Zakona o agenciji za borbu protiv korupcije, bilo adekvatnije sa stanovišta preciznosti, budući da taj Zakon nije sadržao tako šturu odredbu koja je sadržana u važećem ZSK, a kojom se definiše pojam javne funkcije. Prethodno važeći Zakon o agenciji za borbu protiv korupcije je javnu funkciju definisao kao funkciju u organima Republike Srbije, autonomne pokrajine, jedinice lokalne samouprave, organima javnih preduzeća i privrednih društava, ustanova i drugih organizacija, čiji je osnivač, odnosno član Republika Srbija, autonomna pokrajina, jedinica lokalne samouprave, kao i funkcija drugih lica koje bira Narodna skupština, što podrazumeva ovlašćenja rukovođenja, odlučivanja, odnosno donošenja opštih ili pojedinačnih akata, pri čemu usled tako definisanog pojma javne funkcije, nije moguće braniti gore izneto tumačenje, a koje je omogućeno stupanjem na snagu ZSK.

Sa druge strane, ukoliko se uzme u obzir činjenica da su političke stranke danas ključni faktor u oblikovanju političkog života, što potvrđuje i URS, tj. da služe za generisanje pojedinačnih volja građana i usmeravanje delovanja predstavnika naroda u javnim institucijama vlasti (Manojlović, 2015: 147), teško bi se sa uspehom mogla braniti teza da predsednik političke stranke ne vrši „profesionalnu delatnost“ koja je jednako zabranjena predsedniku države, kao i istovremeno vršenje druge javne funkcije (Stevanović, 2019: 319).

Pored toga, izražavanje državnog jedinstva kao propisane ustavne obaveze, zahteva odstupanje od bilo kakvih partikularnih, naročito stranačkih interesa koje bi predsednik političke stranke, ukoliko se već nalazi na njenom čelu, sasvim legitimno i trebalo da zastupa. S tim u vezi, član 50 stav 1. ZSK predviđa da: „Funkcioner može da vrši funkciju u političkoj stranci, odnosno političkom subjektu i da učestvuje u njenim aktivnostima ako to ne ugrožava vršenje javne funkcije i ako to nije zakonom zabranjeno" treba tumačiti na način da je kumuliranje javnih i političkih funkcija dozvoljeno narodnim poslanicima i članovima vlade, pod uslovom da poštuju odredbu navedene odredbe ZSK, dok bi predsednika države iz te mogućnosti trebalo da bude izuzet iz razloga specifičnosti te funkcije (Stevanović, 2019: 319).

Agencija je dajući odgovor na pitanje inkompatibilnosti funkcije predsednika države i predsednika političke stranke, u obzir uzela ustavne garantije koje se odnose na 


\section{Zbornik IKSI, 2-3/2020 - A. Stevanović \\ „Normativni okvir Republike Srbije kojim je regulisano pitanje sukoba interesa - sa osvrtom na praksu Agencije za sprečavanje korupcije”, (str. 75-91)}

pravo političkog udruživanja, te činjenice da politička stranka po definiciji ima ulogu u demokratskom oblikovanju volje građana. Oslanjajući se na navedeno, Agencija je u Mišljenju ${ }^{12}$ od 15. maja 2020. godine (za vreme važenja prethodnog Zakona o agenciji za borbu protiv korupcije) zauzela stav da predsednik države može istovremeno biti i predsednik političke stranke, budući da on pri obavljanju dužnosti predsednika političke stranke nema privatni interes, koji bi eventualno favorizovao na uštrb javnog koji je dužna da zastupa kao javni funkcioner. Sa tim stavom se izričito ne slažemo, budući da on nije u skladu sa duhom uloge predsednika države koju mu namenjuje Ustav, odnosno odredbom važećeg ZSK kojom je definisan pojam javne funkcije i konačno opštim odredbama pozitivnog normativnog okvira koji reguliše sprečavanja sukoba interesa i koji teži preveniranju zloupotrebe javnog na uštrb privatnog interesa, naročito imajući u vidu pomalo naivan stav da javni funkcioner pri vršenju dužnosti predsednika političke stranke ne može imati privatni interes.

Konačno, čini se da je Agencija dajući konkretno Mišljenje, trebalo da utvrdi makar postojanje potencijalnog sukoba interesa i obaveže se da po službenoj dužnosti prati odnosnu situaciju, baš kao i u slučaju kada je davala mišljenje o situaciji gde je narodni poslanik i predsednik Odbora za obrazovanje, nauku, tehnološki razvoj i informatičko društvo, ujedno i predsednik privatnog Univerziteta.

Kada je reč o članu vlade, URS propisuje da on ne može biti narodni poslanik u Narodnoj skupštini, poslanik u skupštini autonomne pokrajine i odbornik u skupštini jedinice lokalne samouprave, niti član izvršnog veća autonomne pokrajine ili izvršnog organa jedinice lokalne samouprave. Predviđeno je da se zakonom uređuje koje su druge funkcije, poslovi ili privatni interesi u sukobu sa položajem člana Vlade.

Agencija je $\mathrm{u}$ jednom od svojih mišljenja ${ }^{13}$ zauzela stav da ministar rudarstva i energetike „ne može istovremeno da vrši i funkciju predstavnika Republike Srbije kao akcionara u Skupštini Društva za istraživanje, proizvodnju, preradu,distribuciju nafte i naftnih derivata i istraživanje i proizvodnju prirodnog gasa „Naftnaindustrija Srbije“ a.d. Novi Sad.“ Takav stav je pravdan činjenicom da je saglasno Zakonu o ministarstvima, „Ministarstvo za rudarstvo i energetiku nadležno za poslove koji se, između ostalog, odnose na: naftnu i gasnu privredu; bezbedan cevovodni transport gasovitih i tečnih ugljovodonika; preduzimanje mera za obezbeđivanje uslova za funkcionisanje javnih preduzeća u oblastima za koje je ministarstvo obrazovano; nadzor u oblastima iz delokruga ministarstva. U nadležnost ministarstva, prema Zakonu o energetici, spada izdavanje dozvola od značaja za poslovanje privrednog društva (energetske dozvole) i sprovođenje nadzora nad radom privrednih društava u ovoj oblasti. Stoga, članstvo ministra u Skupštini ovog privrednog društva može dovesti u sumnju njegovo nepristrasno postupanje u obavljanju javne funkcije, a ujedno dovesti u sumnju ravnopravan položaj drugih, konkurentskih privrednih

\footnotetext{
12 Mišljenje Agencije za sprečavanje korupcije broj: 014-011-00-0119/20-11 od 15.05.2020.

13 Mišljenje Agencije za sprečavanje korupcije broj: 011-00-102/2010-06
} 


\section{Zbornik IKSI, 2-3/2020 - A. Stevanović \\ „Normativni okvir Republike Srbije kojim je regulisano pitanje sukoba interesa - sa osvrtom \\ na praksu Agencije za sprečavanje korupcije”, (str. 75-91)}

društava, čime se ugrožava i ustavno načelo o ravnopravnosti privrednih subjekata u tržišnoj konkurenciji (član 84. Ustava RS).“

Trebalo bi istaći da je ovakav stav Agencije opravdan, naročito ukoliko se uzme u obzir nužnost postojanja odvojenost između vlasničke funkcije i drugih funkcija države koje mogu uticati na uslove poslovanja državnih preduzeća kada je reč o regulaciji tržišta. Utvrđena nespojivost u svemu je saglasna odredbi člana 51. stav 1. važećeg Zakona o sprečavanju korupcije kojim se javnom funkcioneru zabranjuje posedovanje upravljačkih prava u privrednom subjektu.

Uređujući nespojivost sudijske funkcije, URS naročito ističe zabranu političkog delovanja sudije. Ostale zabrane, kao i kod člana vlade, prepušta zakonu da uredi. Zabrana političkog delovanja je u slučaju sudije postavljena najstrože, što je i očekivano s obzirom na apsolutnu nezavisnost kao postulat sudijske funkcije. Sa druge starne, imajući u vidu ulogu političke stranke u sadašnjem društvu, političko delovanje narodnih poslanika i članova vlade bi se moglo opravdati, naravno u granicama i duhu načela profesionalizacije i depolitizacije vlasti.

Konačno, URS propisuje da sudija Ustavnog suda ne može vršiti drugu javnu ili profesionalnu funkciju niti posao, izuzev profesure na pravnom fakultetu u Republici Srbiji, u skladu sa zakonom. Dve su stvari u vezi sa kojima bismo dali napomene kada je reč o načinu na koji je regulisan sukob interesa sudija Ustavnog suda. Prvo, postavlja se pitanje šta je to profesionalna funkcija? Ima li neprofesionalnih? Čini nam se da je ovde reč o redakcijskoj omašci, koja ne bi trebalo da bude svojstvena ustavnoj nomotehnici, te da se u konkretnom slučaju mislilo na profesionalnu delatnost, kao što je to slučaj u članu URS koji reguliše sukob interesa predsednika države (Stevanović, 2019: 320).

\subsection{Zakon o sprečavanju korupcije}

Zakon o sprečavanju korupcije primenjuje se od o1. Septembra 2020. godine. Za razliku od prethodnog Zakona o agenciji za borbu protiv korupcije, definicija sukoba interesa izmeštena je iz tzv. „zakonskog pojmovnika“. Ona je u osnovi ostala ista kao i ranije, te je sukob interesa u našem pozitivnom pravu definisan kao situacija u kojoj funkcioner ima privatni interes koji utiče, može da utiče ili izgleda kao da utiče na postupanje funkcionera u vršenju javne funkcije. Potrebno je napomenuti da se ovaj Zakon odnosi kako na funkcionere, tako i na državne službenike na položaju, što je utvrđeno članom 31. Zakona o državnim službenicima. Otuda je i neshvatljiva korekcija zakonodavca kojom je izmenio definiciju sukoba interesa iz prethodnog Zakona, tako što je iz njenog opsega izbacio deo koji je predviđao da se sukob interesa odnosi i na postupanje lica (službenika po položaju) u vršenju službene dužnosti. Toj konstataciji naročito ide u prilog činjenica da se u većini slučajeva $u$ odnosu na koje je Agencija donosila odluke radilo o službenicima po položaju, a ne javnim funkcionerima.

Postoji nažalost i krug predstavnika vlasti, na koje se ovaj ZSK, kada uređuje materiju sukoba interesa uopšte ne odnosi, dok se na pojedine odnosi rezidualno, što 


\section{Zbornik IKSI, 2-3/2020 - A. Stevanović \\ „Normativni okvir Republike Srbije kojim je regulisano pitanje sukoba interesa - sa osvrtom na praksu Agencije za sprečavanje korupcije", (str. 75-91)}

je čini nam se nedovoljno. Tako je članom 27. Zakona o državnoj upravi ${ }^{14}$ predviđen „poseban savetnik ministra.“ On prema zakonskom opisu posla, po nalogu ministra priprema predloge, sačinjava mišljenja i vrši druge poslove za ministra. Zahvaljujući ovako široko postavljenom delokrugu, njemu je često poveravano upravljanje krupnim projektima kakvi su privatizacijski i tome slično. Različita iskustva su pokazala da su mnogi „posebni savetnici“ bivali u centru korupcionaških afera uz postojanje sukoba interesa, koji se tu podrazumeva. Konačno, oni su „posebni“ i po tome što se njihova prava i obaveze uređuju ugovorom građanskog prava, koji isključuje primenu mnogih instituta službeničkog prava koji čine „zaštitni faktor“ javnog interesa u obavljanju službeničke dužnosti. Iz navedenih razloga smatramo da je „posebne savetnike ministra“ trebalo uključiti u moguće aktere sukoba interesa u smislu ZSK.

ZSK članom 40. načelno sublimira čitavu materiju i daje (obavezne smernice), te zapravo naredne odredbe koje ćemo ovde analizirati predstavljaju njegovu razradu i konkretizaciju. Predviđeno da je funkcioner dužan da javnu funkciju vrši tako da javni interes ne podredi privatnom, da se pridržava propisa koji uređuju njegova prava i obaveze i da stvara i održava poverenje građana u savesno i odgovorno vršenje javne funkcije. Javni funkcioner ne sme biti zavisan od lica koja bi mogla da utiču na njegovu nepristrasnost, niti da koristi javnu funkciju zarad sticanja bilo kakve koristi ili pogodnosti za sebe ili povezano lice. Javnom funkcioneru je zabranjeno da upotrebi, radi sticanja koristi ili pogodnosti sebi ili drugom ili nanošenja štete drugom, informacije do kojih dođe na javnoj funkciji, ako nisu dostupne javnosti.

Agencija je $\mathrm{u}$ više navrata konkretizovala lični interes funkcionera dajući polaznu osnovu za buduća postupanja u situacijama u kojima je za donošenje valjane odluke potrebno utvrditi favorizovanje ličnog interesa od strane funkcionera. Tako je u jednom slučaju utvrđena povreda Zakona od strane direktora škole koji je zaključio ugovore o radu sa ćerkom i bratom ${ }^{15}$, dok je u drugom slučaju Agencija došla do istog zaključka kada je direktor škole zaključio ugovore o radu bliskim srodnicima članova školskog odbora, uz obrazloženje da je na taj način direktor škole pogodovao privatnom interesa na uštrb javnom, odnosno da nije obavestio Agenciju o potencijalnom sukobu interesa u kojem se našao. ${ }^{16}$

Član 45. ZSK reguliše pitanje nespojivosti poslova sa vršenjem javne funkcije pa tako predviđa da javni funkcioner koji u trenutku stupanja na javnu funkciju obavlja drugi posao ili delatnost dužan je da u roku od 15 dana od dana stupanja na javnu funkciju obavesti Agenciju o obavljanju tog posla ili delatnosti. Agencija, po prijemu obaveštenja, utvrđuje da li se obavljanjem posla, odnosno delatnosti ugrožava nepristrasno vršenje javne funkcije. Ako utvrdi da se obavljanjem posla, odnosno

\footnotetext{
${ }^{14}$ Zakon o državnoj upravi ("Sl. glasnik RS", br. 79/2005, 101/2007, 95/2010, 99/2014, 47/2018 i 30/2018 - dr. zakon).

${ }_{15}$ Rešenje Agencije za sprečavanje korupcije broj: 014-020-00-0140/17-11 od 25.09.2017.

${ }^{16}$ Rešenje Agencije za sprečavanje korupcije broj: 014-020-00-0025/18-11 od 18.09.2018.
} 


\section{Zbornik IKSI, 2-3/2020 - A. Stevanović \\ „Normativni okvir Republike Srbije kojim je regulisano pitanje sukoba interesa - sa osvrtom na praksu Agencije za sprečavanje korupcije", (str. 75-91)}

delatnosti iz stava 2. ovog člana ugrožava nepristrasno vršenje javne funkcije, Agencija donosi odluku kojom određuje rok, koji ne može biti duži od 60 dana, u kojem je javni funkcioner dužan da prestane sa obavljanjem tog posla, odnosno delatnosti. Ako javni funkcioner ne postupi u roku iz stava 3. ovog člana,Agencija sprovodi postupak za utvrđivanje povrede zakona. Ako Agencija ne obavesti javnog funkcionera u roku od 30 dana od dana prijema obaveštenja iz stava 1. ovog člana, smatra se da javni funkcioner može da nastavi da obavlja drugi posao ili delatnost.

Propisano je i da javni funkcioner ne može da obavlja drugi posao ili delatnost za vreme vršenja javne funkcije koji zahtevaju rad sa punim radnim vremenom ili stalni rad. Izuzetno, javni funkcioner može da se bavi naučnoistraživačkim radom, nastavnom, kulturno-umetničkom, humanitarnom i sportskom delatnošću, bez saglasnosti Agencije, ako time ne ugrožava nepristrasno vršenje i ugled javne funkcije. Prihode od ovih poslova, odnosno delatnosti, javni funkcioner je dužan da prijavi Agenciji.

Agencija je iznela Mišljenje ${ }^{17}$ prema kojem učešće državnog sekretara, odnosno pomoćnika ministra u naučnoistraživačkim projektima ne bi dovelo do kršenja odredaba Zakona o sprečavanju korupcije kojim je regulisana materija sukoba interesa, jer rad na naučnoistraživačkim projektima potpada pod naučnoistraživački rad u smislu člana 46. stav 2. ZSK, a ne ugrožava nepristrasno vršenje i ugled javne funkcije.

U situacijama kada javni funkcioner istovremeno obavlja i drugi posao ili delatnost, bez saglasnosti Agencije, po pravilu se utvrđuje povreda Zakona i izriče mera javnog objavljivanja povrede Zakona. ${ }^{18}$ Ista mera donosi se i u slučaju povrede odredbe Zakona kojom je javnim funkcionerima zabranjeno da za vreme trajanja funkcije budu osnivači, zastupnici pravnih lica u privatnoj svojini, odnosno da u odnosu na njih poseduju upravljačka prava. Kao olakšavajuća okolnost se naročito uzima činjenica da je lice započelo postupak prenosa ili gašenje prava prema pravnom licu kod nadležne Agencije za privredne registre, odnosno da je pre donošenje rešenja prestalo da poseduje i vrši upravljačka prava u pravnom licu sa privatnim kapitalom. ${ }^{19}$

Predmetnim Zakonom regulisano je pitanje vršenja funkcija u političkoj stranci, odnosno političkom subjektu, od strane javnog funkcionera. Načelno je predviđeno da javni funkcioner može da vrši funkciju u političkoj stranci, odnosno političkom subjektu i da učestvuje u njihovim aktivnostima, ako to ne ugrožava vršenje javne funkcije i ako to nije zakonom zabranjeno. Javni funkcioner ne može da koristi javne resurse i skupove na kojima učestvuje i susrete koje ima u svojstvu javnog funkcionera za promociju političkih stranaka, odnosno političkih subjekata. Izuzetno, javni funkcioner može da koristi javne resurse radi zaštite lične

${ }_{17}$ Mišljenje Agencije za sprečavanje korupcije broj: 011-00-205/2010-06

${ }^{18}$ Rešenje Agencije za sprečavanje korupcije broj: 014-020-00-0212/16-11 od 17.05.2017.

19 Rešenje Agencije za sprečavanje korupcije broj: 014-020-00-0006/2013-11 od 19.04.2013. 


\section{Zbornik IKSI, 2-3/2020 - A. Stevanović \\ „Normativni okvir Republike Srbije kojim je regulisano pitanje sukoba interesa - sa osvrtom na praksu Agencije za sprečavanje korupcije”, (str. 75-91)}

bezbednosti, ukoliko je takva upotreba javnih resursa uređena propisima iz te oblasti ili odlukom službi koje se staraju o bezbednosti javnih funkcionera.

Kada je reč o potencijalnom političkom diskursu i javnoj debati, javni funkcioner je dužan da uvek nedvosmisleno predoči sagovornicima i javnosti da li iznosi stav organa u kojem vrši javnu funkciju ili stav političke stranke, odnosno političkog subjekta, što se ne odnosi na javne funkcionere koji su izabrani neposredno od građana čime je ovom krugu funkcionera obezbeđena naročita predstavnička uloga.

U praksi je pregršt primera koji se nalaze na samoj granici dozvoljenog, kada je reč prethodno navedenom pravilu koje postavlja ZSK. ${ }^{20}$ Fenomen „funkcionerske kampanje“" ${ }^{21}$ koji je naročito prisutan u nestabilnim demokratskim državama, kakva je i Republika Srbija, obuhvata različite aktivnosti između kojih je teško povući jasnu liniju između dozvoljenog i nedozvoljenog.

\section{ZAKLJUČNA RAZMATRANJA}

Regulisanje sukoba interesa odraz je snažnih demokratskih tendencija u cilju obezbeđivanja fundamentalnih demokratskih principa poput principa podela vlasti, vladavine prava i pravne države. Sa druge strane, proces adekvatnog zakonskog normiranja odnosne materije neizostavno je praćen vanpravnim uticajima, naročito političke prirode, a koji su odraz društvenog, političkog, kulturološkog i ekonomskog stanja društva. Kada je reč o stanju u Republici Srbiji, potrebno je napomenuti da u njoj postoji relativno povoljan zakonski okvir uz upitnu, tj. često selektivnu primenu imperativnih normi.

Primetna je tendencija Agencije za sprečavanje korupcije da sa većim stepenom samopouzdanja i češće poseže za merama poput javnog objavljivana povrede zakona i objavljivanja preporuka za razrešenje sa javne funkcije, onda kada se one odnose na službenike po položaju. Takvo stanje stvari se može objasniti pretpostavljeno manjim političkim uticajem tih službenika, za razliku od javnih funkcionera. Ne bi trebalo izostaviti ni činjenicu da je rad službenika po položaju često „ispod radara“ javnosti pa samim tim pojedini bivaju ohrabreni da češce nastoje da povredama

\footnotetext{
2o Jedan od skorijih primera koji o tome govori je i situacija u kojoj je direktor preduzeća „Milan Blagojević - Namenska“ iz Lučana, neposredno pred lokalne izbore, javno i otvoreno pozvao svoje zaposlene da glasaju za stranku, učesnika na tim izborima, čiji je on pri tom član. Postupajući po podnetoj prijavi, Agencija za borbu protiv korupcije je donela je Rešenje o obustavi postupka smatrajući, prema našem mišljenju pogrešno i suprotno duhu i svrsi zakona, da u konkretnom slučaju nije povređen član 29. stav 2. tada važećeg ZABK iz razloga što je stranačko agitovanje koje ZABK eksplicitno zabranjuje, pomenuti direktor vršio na skupu koji je organizovan od strane dobrovoljnih davalac krvi iz redova zaposlenih (sindikata) i Crvenog krsta.

21 Vlada Republike Srbije je 23.09.2019. na osnovu preporuka Radne grupe za saradnju sa Organizacijom za evropsku bezbednost i saradnju i Kancelarijom za demokratske institucije i ljudska prava, donela Zaključak u kojem se zabranjuje funkcioneru da svoje aktivnosti u svojstvu predstavnika javne vlasti, zloupotrebljava za izbornu promociju svoje stranke, čime je usled različitih političkih zbivanja, priznala postojanje ukorenjene loše prakse koja razara demokratiju.
} 


\section{Zbornik IKSI, 2-3/2020 - A. Stevanović \\ „Normativni okvir Republike Srbije kojim je regulisano pitanje sukoba interesa - sa osvrtom na praksu Agencije za sprečavanje korupcije", (str. 75-91)}

zakona ostvare svoj privatni interes na štetu javnog koji bi trebalo da zastupaju. U svakom slučaju, opšti je zaključak da pojedini nedovoljno definisani instituti i pojmovi, kao što je slučaj sa pojmom javne funkcije u novom Zakonu o sprečavanju korupcije, stimulišu stanje stvari koje se može opisati kao „mreža koja hvata sitnu, a propušta krupnu ribu." Utisak je takođe i da novi Zakon o sprečavanju korupcije nije rešio određena problematična mesta, makar kada se radi o delu Zakona kojim se uređuje sprečavanje sukoba interesa.

Konačno, pri razmatranju značaja valjanog regulisanja materije sukoba interesa za društvo, trebalo bi se složiti sa tvrdnjom da se on ne ogleda isključivo u sprečavanju materijalne ili finansijske štete koja je po pravilu, itekako velika i predstavlja važnu prepreku ka normalnom funkcionisanju i razvoju društva, naročito u nestabilnim i demokratski nekonsolidovanim državama. Normiranjem sprečavanja sukoba interesa, naročito pri vršenju javne vlasti, pre svega bi trebalo nastojati da se zaštiti poverenje građana $\mathrm{u}$ institucije vlasti i njihove predstavnike, te da se obezbedi integritet eksponenata vlasti na osnovu kojeg bi oni crpeli legitimitet za vršenje svojih dužnosti. Sve to naravno zavisi od mnogih vanpravnih elemenata koje jednim imenom možemo označiti kao „politička volja“, ali i od načina na koji se ti propisi primenjuju, pri čemu tu imamo u vidu i kapacitete tela koja su nadležna da se bave pitanjem sukoba interesa.

\section{LITERATURA}

(1) Čavoški, K. (1995) Ustav kao jemstvo slobode. Beograd: Filip Višnjić.

(2) Fatić, A. (2005) Korupcija i kriminalna devijacija. U: Radovanović, D., Bulatović, A. (ur.) Korupcija. Beograd: Centar za menadžment i Institut za kriminološka i sociološka istraživanja.

(3) Jovanović, M. (2007) Demokratska konsolidacija i politička korupcija - slučaj Srbije. U: Ilić P.G (ur.) Korupcija - osnovni pojmovi i mehanizmi za borbu. Beograd: Pravni fakultet Univerziteta u Beogradu.

(4) Kernaghan, K, Langford, JW. (1990) The responsible public servant. New York: The Institute for Research on Public Policy.

(5) Lubarda, B. (2007) Zabrana sukoba interesa i prevencija korupcije. U: Ilić, P.G. (ur.) Korupcija - osnovni pojmovi i mehanizmi za bornu. Beograd: Pravni fakultet Univerziteta u Beogradu.

(6) Luhmann, N. (1979) Trust \& Power. New York: John Wiley \& Sons.

(7) Manojlović, S. (2015) Finansiranje političkih stranaka iz javnih i(li) privatnih izvora - Kolika je cena pravednog stranačkog sistema? U: Radović, M. (ur) HARMONIUS Journal of Legal and Social Studies in South East Europe.

(8) Nenadić N, et al. (2016) Praćenje napretka u oblasti sprečavanja i rešavanja sukoba javnog i privatnog interesa kod javnih funkcioner i javnih službenika $u$ RepubliciSrbiji. Beograd: Transparentnost - Srbija.

(9) Rao S., Marquette H. (2012) Corruption indicators in Performance Assessment Frameworks for Budget Support. Norway: Anti-Corruption Resource Centre.

(10) Stevanović, A. (2019) Pojam sukoba interesa u teoriji i zakonodavstvu Republike Srbije. U: Kostić, J. \& Stevanović, A. (ur.) Finansijski kriminalitet i korupcija, Beograd: Institut za uporedno pravo i Institut za kriminološka i sociološka istraživanja. 
Zbornik IKSI, 2-3/2020 - A. Stevanović

„Normativni okvir Republike Srbije kojim je regulisano pitanje sukoba interesa - sa osvrtom

na praksu Agencije za sprečavanje korupcije”, (str. 75-91)

(11) Stojanović, D. (1991) Ustav i političko zakonodavstvo Republike Srbije. Niš: Institut za pravna i društvena istraživanja Pravnog fakulteta u Nišu.

(12) Vukadinović, J., Glintić, M. (2013) Sukob interesa. U: Rabrenović, A. (ur.) Pravnimehanizmi sprečavanja korupcije u zemljama Jugoistočne Evrope. Beograd: Institut za uporedno pravo.

(13) Vuković, S. (2003) Korupcija i vladavina prava. Beograd: Institut društvenih nauka.

\section{Zakon i drugi pravni izvori}

(14) Ustav Republike Srbije ("Sl. glasnik RS", br. 98/2006).

(15) Zakon o agenciji za borbu protiv korupcije ("Sl. glasnik RS", br. 97/o8, 53/10, 66/11-US, 67/13-US i 8/15-US)

(16) Zakon o državnim službenicima ("Sl. glasnik RS", br. 79/2005, 81/2005 - ispr., 83/2005 - ispr., 64/2007, 67/2007 - ispr., 116/2008, 104/2009, 99/2014, 94/2017 i 95/2018).

(17) Zakon o državnoj upravi ("Sl. glasnik RS", br. 79/2005, 101/2007, 95/2010, 99/2014, 47/2018 i 30/2018 - dr. zakon).

(18) Zakon o lokalnoj samoupravi ("Sl. glasnik RS", br. 129/2007, 83/2014 - dr. zakon, 101/2016 - dr. zakon i 47/2018).

(19) Zakon o sprečavanju korupcije ("Sl. glasnik $R S$ ", br. 35/2019).

(20) Mišljenje Agencije za sprečavanje korupcije broj: 011-00-205/2010-06

(21) Mišljenje Agencije za sprečavanje korupcije broj: 014-011-0o-0119/20-11 Mišljenje Agencije za sprečavanje korupcije broj: 011-00-102/2010-06

(22) Mišljenje Agencije za sprečavanje korupcije broj: 014-011-0o-0167/16-11

(23) Mišljenje Agencije za sprečavanje korupcije broj: 014-011-00-0189/17-11

(24) Rešenje Agencije za sprečavanje korupcije broj: 014-020-00-0006/2013-11 od 19.04.2013.

(25) Rešenje Agencije za sprečavanje korupcije broj: 014-020-00-0025/18-11 od 18.09.2018.

(26) Rešenje Agencije za sprečavanje korupcije broj: 014-020-00-0140/17-11 od 25.09.2017.

(27) Rešenje Agencije za sprečavanje korupcije broj: 014-020-00-0212/16-11 od 17.05.2017. 


\section{NORMATIVE FRAMEWORK OF THE REPUBLIC OF SERBIA REGULATING THE ISSUE OF CONFLICTS OF INTEREST - WITH REFERENCE TO THE PRACTICE OF THE AGENCY FOR THE PREVENTION OF CORRUPTION}

This paper considers the phenomenon of conflict of interest focusing on its main characteristics and manifestations in the normative framework of the Republic of Serbia. Normative concept depends on a variety of socio-political, cultural, economic, historical, traditional and other factors, so it could be concluded that conflict of interest is a kind of social construct. This means that it is necessary to take into account all of these causes in the notional definition of conflict of interest in relation to each individual society. The conflicts of different interests are an integral part of life in an organized community, and we can reasonably argue that the quality of such life to a large extent depends on the proper definition of the concept of conflict of interest and accordingly its adeqate regulation. The general conclusion is that some insufficiently defined institutes and concepts, such as the notion of public office in the new Law on Prevention of Corruption, stimulate the state of affairs, which can be described as "a net that catches small and lets big fish through." The new Law on Prevention of Corruption, which has not resolved certain problematic areas, at least when it comes to the part of the Law dedicated to the prevention of conflicts of interest.

KEY WORDS: conflict of interest / corruption/ democratic institutions/ public authorities/ Agency for Prevention of Corruption / Law on Prevention of Corruption 
